Carta ao Editor

\title{
OS DENDRÔMETROS SERIAM FITOTENSIÔMETROS OU FITOTURGÔMETROS?
}

O estado hídrico de órgãos vegetais em aplicações de ecofisiologia tem sido avaliado com o emprego de dendrômetros. Os dendrômetros são equipamentos usados para medir as variações do perímetro de órgãos vegetais no tempo e servem para fazer inferências sobre o estado hídrico da planta. Nos caules, o diâmetro diminui durante as horas mais quentes do dia, enquanto a taxa de transpiração está mais elevada. A defasagem temporal que se observa entre a taxa de transpiração e o diâmetro medido deve-se ao armazenamento e à dissipação de volumes de água no próprio caule e em outras partes da planta.

Tendo em mente a teoria coeso-tenso-transpiratória, imaginou-se que essa diminuição do diâmetro do caule seria causada pela tensão que arrasta a água das raízes para a folhas. Possivelmente por essa razão, os dendrômetros freqüentemente tem sido denominados fitotensiômetros. Uma interpretação dessa variação do diâmetro do caule envolve aspectos morfológicos e anatômicos. Tipicamente, o caule é formado de madeira e casca. Na madeira, o interior morto é denominado lenho e a parte externa viva é denominada alburno. No lenho, a matriz fibrosa e umedecida troca água com o alburno de acordo com as variações da tensão da água na planta. O transporte de água entre as diversas camadas do lenho não envolve membranas semi-permeáveis e, dependendo da espécie, o lenho pode ainda conter vasos de xilema funcionais. O lenho parece se tratar de um sistema físico, no qual as variações de volume são função apenas da tensão de água na planta, visto que sem membranas semipermeáveis não há como pensar em pressão de turgescência e fica difícil pensar em pressurizações compartimentalizadas.

No alburno, o apoplasma é composto por todas as paredes celulares, mais o volume interno dos vasos do xilema. O volume do apoplasma do alburno é determinado apenas pela tensão da água no caule. A maior parte do volume do alburno, no entanto, é formada pelo protopasto das células vivas conectadas por plasmodesmos de um sistema supracelular de unidade e interações mal compreendidas denominado simplasma. O volume do simplasma é governado pela pressão de turgescência e um módulo de elasticidade linear Hoockiano. Calbo \& Pessoa [A plant growth re-analysis, R.Bras.Fisiol.Veg. 6(2): 1994] tratam com algum detalhamento as funções da pressão de turgescência sobre a tensão da água na determinação do volume vegetal e no seu crescimento. 
Diferentemente, em plantas herbáceas sem um lenho, o caule formado de células de paredes mais delgadas tem o seu diâmetro ou o seu perímetro determinado pelo módulo de elasticidade linear das paredes celulares e pela pressão de turgescência. O mesmo tipo de raciocínio se aplicaria ao uso de dendrômetros para acompanhar as variações de perímetro desses caules e de outros órgãos constituídos de tecidos com grande predominância de células parenquimatosas com paredes celulares delgadas. Nos casos considerados neste parágrafo, o dendrômetro seria um tipo de turgômetro e não um fitotensiômetro, como ocorre em caules de plantas perenes e lenhosas, nas quais há uma dominância quase absoluta de tecidos apoplasmicos cujo volume é uma função da tensão da água na planta.

Essas considerações sobre a interpretação física de resultados quantitativos obtidos com dendrômetros parecem relevantes e podem possuir conseqüências surpreendentes à luz da extensão da teoria de Lockhart para o crescimento das plantas apresentada no trabalho "A plant growth re-analysis", previamente citado.

Ao contrário das medições dendrométricas, que podem significar medições de tensão da água ou de pressão de turgescência, dependendo da constituição das amostras vegetais, outros métodos como a pressurização em câmara-de-pressão, as medições de fluxo de seiva e as medições porométricas de absorção de água são sempre medições dependentes da tensão da água na planta. Se a teoria coeso-tensotranspiratória for verdadeira, então, para estes equipamentos, é mais adequado a denominação fitotensiômetro, previamente aplicada para os dendrômetros.

\section{Dr. Adonai Gimenez Calbo EMBRAPA/CNPH}

